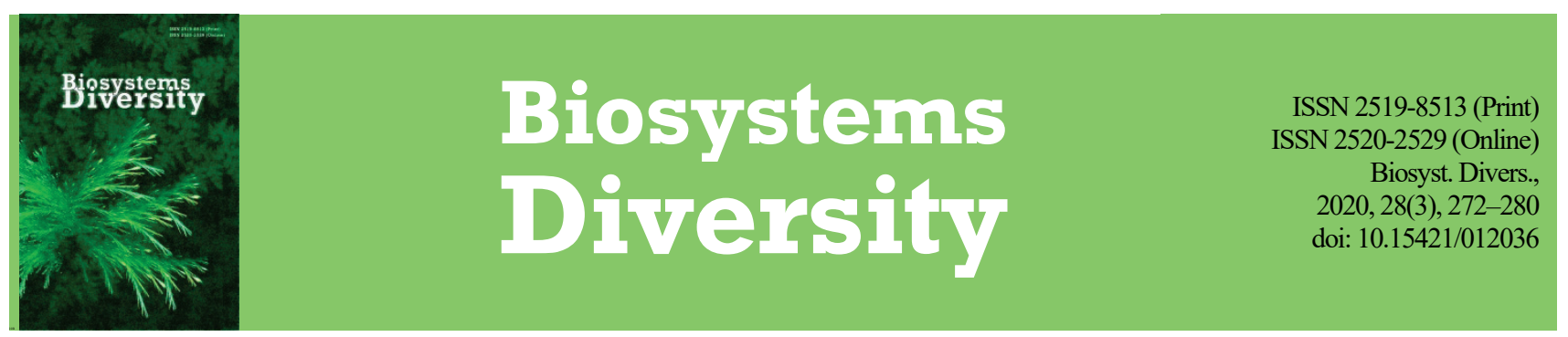

\title{
Influence of herbicides, insecticides and fungicides on food consumption and body weight of Rossiulus kessleri (Diplopoda, Julidae)
}

\author{
V. M. Kozak*, E. R. Romanenko**, V. V. Brygadyrenko**** \\ *Oles Honchar Dnipro National University, Dnipro, Ukraine \\ **Dnipro State Agrarian and Economic University, Dnipro, Ukraine
}

Article info

Received 15.06.2020

Received in revised form 01.08 .2020

Accepted 02.08.2020

Oles Honchar Dnipro National University, Gagarin Ave., 72, Dnipro, 49010, Ukraine. Tel.: +38-050-939-07-88 E-mail:brigad@ua.fm

Dnipro State Agrarian and Economic University, S. Efremov st., 25 ,

Dnipro, 49600, Ukraine.

Tel: $+38-098-975-97-13$

E-mail:

michaeled1698@hotmail.com

Kozak, V. M., Romanenko, E. R., \& Brygadyrenko, V. V. (2020). Influence of herbicides, insecticides and fungicides on food consumption and body weight of Rossiulus kessleri (Diplopoda, Julidae). Biosystems Diversity, 28(3), 272-280. doi:10.15421/012036

Pesticides kill organisms harmful for the human organism, sometimes also harming beneficial ones. After treatment, pesticides remain on the soil surface in agrocenoses and adjacent plots for decades. For the laboratory experiment, we selected Rossiulus kessleri (Lochmander, 1927) - a species which lives 5-6 years on the soil surface and can dig in to soil to a depth of 30-40 $\mathrm{cm}$. During a 20-day experiment we used herbicides (Roundup, Urahan Forte), insecticides (Omite, BI 58, Biotlin, Actellic, Nurelle D) and fungicides (Ridomil Gold, Thiovit Jet, Penncozeb 80 WP, Falcon, Tilt, Horus) which are often used in agrocenosises of Ukraine. Under the impact of Roundup and Urahan, body weight of $R$. kessleri reliably did not change, but food consumption and production of excrement increased. Pesticide-treated litter did not digest in the intestine of millipedes, but they survived to the end of the experiment (20 days). In the conditions of treating litter with insecticides Omite, BI 58, Biotlin, Actellic and Nurelle D, the amount of consumed food and body weight reliably did not change; most of these insecticides slowed the formation of feces in the millipedes. The highest studied concentrations of Actellic and Nurelle D preparations caused death to $R$. kessleri. Depending on the concentration in the litter, the studied fungicides Ridomil Gold, Thiovit Jet, Penncozeb, Falcon, Tilt, Horus had a varying effect on food consumption, body weight and the amount of excrement of $R$. kessleri. Thus, in agrocenoses and forest ecosystems adjacent to them (windbreaks, ravine and flood plain forests), $R$. kessleri can be significantly affected by the manufacturer-recommended doses of pesticides, as well as more than ten-fold lower doses.

Keywords: Myriapoda; glyphosate; Propargite; Mefenoxam; Mancozeb; Dimethoate; Imidacloprid; Pirimiphos-methyl; Chlorpyrifos; Cypermethrin; Tebuconazole; Triadimenol; Spiroxamine; Propiconazole; Cyprodinil.

\section{Introduction}

Contemporary agricultural production is impossible without pesticides. Monocultures (fields, gardens, forest plantations) are treated with various types of substances, each affecting living organisms in different ways (Relyea, 2004; Birkhofer et al., 2016). Pesticides negatively affect living organisms of non-target taxonomic groups, often harming animals that are not harmful for plants cultivated by people (Ebregt et al., 2005; Adamski et al., 2007). The general population and farmers in the territory of Ukraine most often use such insecticides, fungicides and herbicides as Roundup, Urahan Forte, Omite, Ridomil Gold, BI 58, Biotlin, Thiovit Jet, Penncozeb 80 WP, Actellic, Nurelle D, Falcon, Tilt, and Horus.

Roundup is a herbicide the main active ingredient of which is isopropylamine salt of glyphosate. When glyphosate penetrates the cells of plants, it blocks the synthesis of chorismic acid and shikimic acid. This results in blocking the synthesis of phenylalanine, tyrosine and tryptophan, and also terpenoid quinines, phenols, tocopherols, separate alkaloids and phytohormones in plants. This does not only affect plants, similar processes occur in some microorganisms. Another essential component of Roundup is polyoxyethylene amine (POEA), which increases the penetration of glyphosate to the organisms of humans and animals. Urahan Forte is a herbicide the main active ingredient of which is glyphosate potassium salt. The preparation penetrates into the plant over 2-3 hours.

Omite is an insecticide most often used against spider mites. The preparation displayed lower activity towards insects and millipedes. Its main active substance is propargite.

Ridomil Gold is a fungicide which has preventive and treatment effects against downy mildew, late blight (Phytophthora infestans) and moths. The preparation`s active substances are mancozeb and mefenoxam.
BI 58 is an insecticide with active substance dimethoate. In acidic environments, there forms O-dimethoate with heightened toxicity for warmblooded animals and insects. However, this compound is unstable and quickly decomposes to phosphorus acid. Biotlin is an insecticide which is often used against aphids. Its main active agent is imidacloprid, which belongs to the class of neonicotinoids. The preparation blocks the functioning of the postsynaptic acetylcholine receptor of the central nervous system of arthropods, leading to paralysis and death. Thiovit Jet is a fungicide against downy mildew, etc. Its active agent is sulfur. After spraying, it remains on the surface of plants and foliage for a long time.

Penncozeb $80 \mathrm{WP}$ is a contact fungicide against diseases of vegetables, fruit-bearing plants and vineyards. Its active agent is Mancozeb. Manganese and zinc in the active substance provide simultaneous effect against the diseases and extra-root nutrition with the mentioned microelements, activating photosynthesis, therefore allowing higher yield to be obtained. Actellic is an insecticide of the group of phosphor-organic compounds. It is an intestinal contact fungicide with killing power against many insect pests of fruit-bearing plants and plant-feeding mites, including some spider mites. Nurelle D is an insecticide the main active substances of which are Cypermethrin and Chlorpyrifos. The preparation is considered low-toxic for birds, bees and aquatic organisms.

Falcon is a fungicide the active agents of which are tebuconazole, triadimenol, and spiroxamine. All the agents included in the content of fungicide Falcon (two substances of the azole group - triadimenol and tebuconazole, and a representative of class of spiroketalamines - spiroxamine) contribute to biosynthesis of sterols without participation of methyl at different levels, impair selectivity of cellular walls of the fungus regarding allowing access of various compounds to the cytoplasm, ultimately leading to death of pathogenic microorganisms. Tilt is a systemic 
fungicide for protection of cereal crops against a complex of leaf and ear diseases, and also protection of berry plants and fodder herbs. The main active agent is propiconazole. Horus is a systemic fungicide for protection of fruit-bearing plants against a complex of diseases, particularly protection of grapevines against fungi pathogens. The main active agent of the preparation is cyprodinil. Cyprodinil impairs biosynthesis of methionine in fungus cells.

To determine how strong the effects of these substances on invertebrates are, it is practical to test the commonest of them. Millipedes of the Julidae family are phytosaprophages which consume mostly foliage of grasses, shrubs and trees (Byzov, 2006). The Julidae fauna of Ukraine and the European part of the former USSR is studied unevenly (Striganova \& Prishutova, 1990; Prisnyi, 2002; Golovatch, 2008; Golovatch \& Kime, 2009; Evsyukov \& Golovatch, 2013; Kokhia \& Golovatch, 2020).

Julidae play an important role (Gere, 1956; Brygadyrenko, 2015, 2016) in functioning of both agrocenoses and adjacent natural ecosystems (forests, steppes, meadow areas). The effect of chemical pollutants on the organisms of Julidae is not studied sufficiently (Brygadyrenko \& Ivanyshyn, 2015; Douglas et al., 2017, 2019; Kozak \& Brygadyrenko, 2018; De Souza et al., 2019; Tóth \& Hornung, 2019), while the effect of agrochemicals is practically unstudied. The most abundant diplopod in Central and Southern Ukraine is Rossiulus kessleri (Lochmander, 1927). The effect of agrochemicals on this species still remains unstudied (Svyrydchenko \& Brygadyrenko, 2014).

The objective of the article was to evaluate the effects of the most common pesticides in Ukraine on the food consumption, changes in body weight, formation of feces and mortality of $R$. kessleri.

\section{Materials and methods}

The experiment started with collection of the material for the study R. kessleri millipedes. They were collected $10 \mathrm{~km}$ away from the city, near Dnipropetrovsk Airport. Specimens of R. kessleri were collected manually during several days in late June (over 2,000 individuals of $R$. kessleri were collected). The millipedes were captured manually in the litter of a ravine forest area. Litter, the trophic resource of millipedes, was collected manually using special sieves which helped remove twigs and garbage from the leaves. We used sieves with the cells of 12.0 and $3.5 \mathrm{~mm}$. The collected plant material was transferred to the laboratory of the Department of Zoology and Ecology of Dnipro National University and was dried for two weeks. Dry litter was equally ( $2 \mathrm{~g}$ in each) distributed in plastic cups of $200 \mathrm{~mL}$ capacity. The number of cups equaled the number of millipedes. The millipedes were weighed with the accuracy of up to $0.1 \mathrm{mg}$, their sex was determined, and they were divided to cups. Pesticides (Table 1) were dissolved in distilled water. Using a pipette with a solution of pesticides ( $3.5 \mathrm{~mL}$ ) or distilled water (in the control), the litter in the cups was moistened. Each variant of the experiment was performed in 10-fold replication (for each experiment, we used 5 males and 5 females with average body weight; the largest and smallest individuals according to the body weight were not taken into the experiment). The experiment lasted for 20 days. To maintain optimum moisture during the experiment, $2 \mathrm{~mL}$ of distilled water was added to the substrates in the cups each three days. After the experiment, the millipedes were weighed again and the litter was dried, excrement was removed and weighed as well. All the weighing procedures were performed with the accuracy of up to $0.1 \mathrm{mg}$.

The results were statistically analyzed, determining the mean value, median, standard deviation (SD), and the first and the third quartiles for each characteristic in all the variants of the experiment. The selections were compared using single-factor dispersion analysis (ANOVA) with Bonferroni correction, considering differences between the selections reliable at the level of $\mathrm{P}<0.05$. All calculations and developments of diagrams were made in Statistica 8.0 software (StatSoft, USA, 2012).

\section{Results}

Impact of herbicides Roundup and Urahan Forte on R. kessleri. Under the effect of the preparation, Roundup, $R$. kessleri reliably increased their food consumption (Fig. 1a) in three variants of the experiment with highest doses of the herbicide $\left(2.8 \cdot 10^{-1}, 2.8 \cdot 10^{-2}\right.$ and $2.8 \cdot 10^{-3} \mathrm{mg}$ of isopropylamine salt of glyphosate/g of litter). This was an unexpected result, because the opposite seemed more likely, namely slowing of food consumption due to impact of the pesticide Roundup. For other variants of the experiment, the median of the amount of consumed food ranged within 9-15 mg/day. No reliable changes in the body weight of $R$. kessleri under the influence of Roundup were observed (Fig. 1b). The median weight gain of $R$. kessleri for all the variants of the experiment ranged at the level of $0.1-0.6 \mathrm{mg} / 24 \mathrm{~h}$. The rates of formation of excrement (Fig. 1c) increased in both variants of the experiment with maximum concentrations of pesticide $\left(2.8 \cdot 10^{-2}\right.$ and $2.8 \cdot 10^{-3} \mathrm{mg}$ of isopropylamine salt of glyphosate/g of litter). In the other variants of the experiment, the median of the tempi of formation of excrement ranged within 9-13 mg/24 h.

Potassium salt of glyphosate in the concentration of $3 \cdot 10^{-3} \mathrm{mg} / \mathrm{g}$ of litter reliably increased food consumption by millipedes (Fig. 2a). For the $3 \cdot 10^{-1}, 3 \cdot 10^{-2} \mathrm{mg} / \mathrm{g}$ concentration of pesticide, the differences were unreliable, both in the variant of the experiment without $R$. kessleri, and the variant without application of this herbicide to the litter. The weight of millipedes in all variants of introduction of the preparation Urahan Forte reliably did not change (Fig. 2b). Similarly to the variant with Roundup, exposure to Urahan Forte (Fig. 2c) was accompanied by the tendency towards increase in the tempi of formation of feces, most pronounced during the use of the highest tested concentration of this pesticide $\left(3 \cdot 10^{-1} \mathrm{mg} / \mathrm{g}\right)$.

Table 1

Brief characteristics of the pesticides used in the experiment

\begin{tabular}{|c|c|c|c|}
\hline Pesticides & Active substance & $\begin{array}{l}\text { Recommended dose } \\
\text { in agrocenoses, } \mathrm{kg} / \mathrm{ha}\end{array}$ & $\begin{array}{c}\text { Doses of preparations } \\
\text { in our survey, } \mathrm{mg} / \mathrm{g} \text { of litter }\end{array}$ \\
\hline Roundup & Isopropylamine salt of glyphosate, $450 \mathrm{~g} / \mathrm{L}$ & $0.5-6.4$ & $2.8 \cdot 10^{-10}-2.8 \cdot 10^{-1}$ \\
\hline Urahan Forte & Potassum salt of glyphosate, $500 \mathrm{~g} / \mathrm{L}$ & $1.5-4.0$ & $3 \cdot 10^{-3}-3 \cdot 10^{-3}$ \\
\hline Omite & Propargite, $570 \mathrm{~g} / \mathrm{L}$ & $0.9-2.2$ & $3.6 \cdot 10^{-3}-3.6 \cdot 10^{-1}$ \\
\hline Ridomil Gold & Mancozeb, $640 \mathrm{~g} / \mathrm{kg}$, Mefenoxam, $40 \mathrm{~g} / \mathrm{kg}$ & 2.5 & $4 \cdot 10^{-3}-4 \cdot 10^{-1}$ \\
\hline $\mathrm{BI} 58 \mathrm{EC}$ & Dimethoate, $380 \mathrm{~g} / \mathrm{L}$ & $0.5-2.8$ & $2.4 \cdot 10^{-3}-2.4 \cdot 10^{-1}$ \\
\hline Biotlin & Imidacloprid, $200 \mathrm{~g} / \mathrm{L}$ & $0.3-0.5$ & $1.2 \cdot 10^{-3}-1.2 \cdot 10^{-1}$ \\
\hline Thiovit Jet & Sulfur, $800 \mathrm{~g} / \mathrm{kg}$ & $2.0-8.0$ & $4.8 \cdot 10^{-3}-4.8 \cdot 10^{-1}$ \\
\hline Penncozeb $80 \mathrm{WP}$ & Mancozeb, $800 \mathrm{~g} / \mathrm{kg}$ & $1.7-1.8$ & $4.8 \cdot 10^{-3}-4.8 \cdot 10^{-1}$ \\
\hline Actellic & Pirimiphos-methyl, $500 \mathrm{~g} / \mathrm{L}$ & $0.4-0.8$ & $3 \cdot 10^{-3}-3 \cdot 10^{-1}$ \\
\hline Nurelle D & Chlorpyrifos, $500 \mathrm{~g} / \mathrm{L}$, Cypermethrin, $50 \mathrm{~g} / \mathrm{L}$ & $0.5-1.0$ & $3 \cdot 10^{-3}-3 \cdot 10^{-1}$ \\
\hline Falcon & Tebuconazole, $167 \mathrm{~g} / \mathrm{L}$, triadimenol, $43 \mathrm{~g} / \mathrm{L}$, spiroxamine, $250 \mathrm{~g} / \mathrm{L}$ & $0.4-0.6$ & $1.1 \cdot 10^{-3}-1.1 \cdot 10^{-1}$ \\
\hline Tilt & Propiconazole, $250 \mathrm{~g} / \mathrm{L}$ & $2.5-5.0$ & $1.5 \cdot 10^{-3}-1.5 \cdot 10^{-1}$ \\
\hline Horus & Cyprodinil, $750 \mathrm{~g} / \mathrm{L}$ & 0.45 & $4.5 \cdot 10^{-3}-4.5 \cdot 10^{-1}$ \\
\hline
\end{tabular}

Influence of insecticides Omite, BI 58, Biotlin, Actellic, Nurelle D on R. kessleri. The preparation Omite reliably did not increase the tempi of food consumption by specimens of $R$. kessleri (Fig. 3a), though the differences between the mass of the litter at the beginning and the end of the experiment in the variants with and without millipedes declined with increase in the concentration of pesticide compared to the control, suggesting cessation of nutrition by most specimens of millipedes. In the tested range of the values, during increase in the concentration of Omite preparation, body weight of $R$. kessleri reliably did not change (Fig. 3b), and the amount of feces reliably decreased (Fig. 3c). At maximum concentration of this pesticide $\left(3.6 \cdot 10^{-1} \mathrm{mg}\right.$ of propargite/g of litter) the median of the amount of excrement increased to $2 \mathrm{mg} / 24 \mathrm{~h}$ compared with $25 \mathrm{mg} / 24 \mathrm{~h}$ per one millipede in the variant of the experiment without application of Omite preparation (Fig. 3c). 

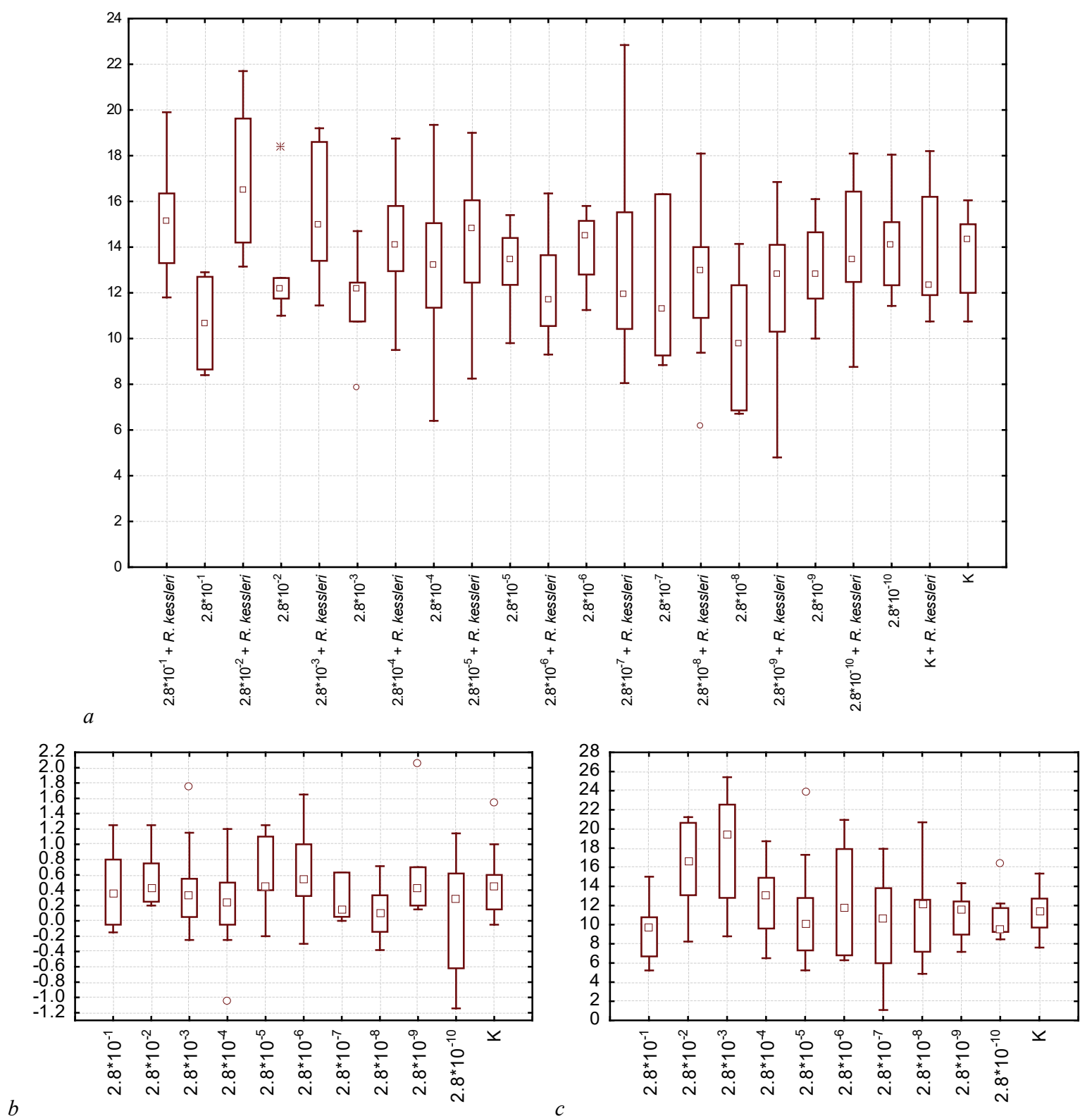

Fig. 1. Change in the food mass $(a)$, body weight of $(b)$, production of feces $(c)$ by individuals of Rossiulus kessleri (Lohm.) during 20-day experiment in the gradient of concentration of Roundup preparation: on the abscissa axis - concentration of active agent of Roundup (isopropylamine salt of glyphosate, $\mathrm{mg} / \mathrm{g}$ of litter), $\mathrm{K}$ - control (without Roundup); on the ordinate axis - mean daily change in the body weight, food or feces $(\mathrm{mg} / 24 \mathrm{~h})$, respectively; $\mathrm{n}=10$
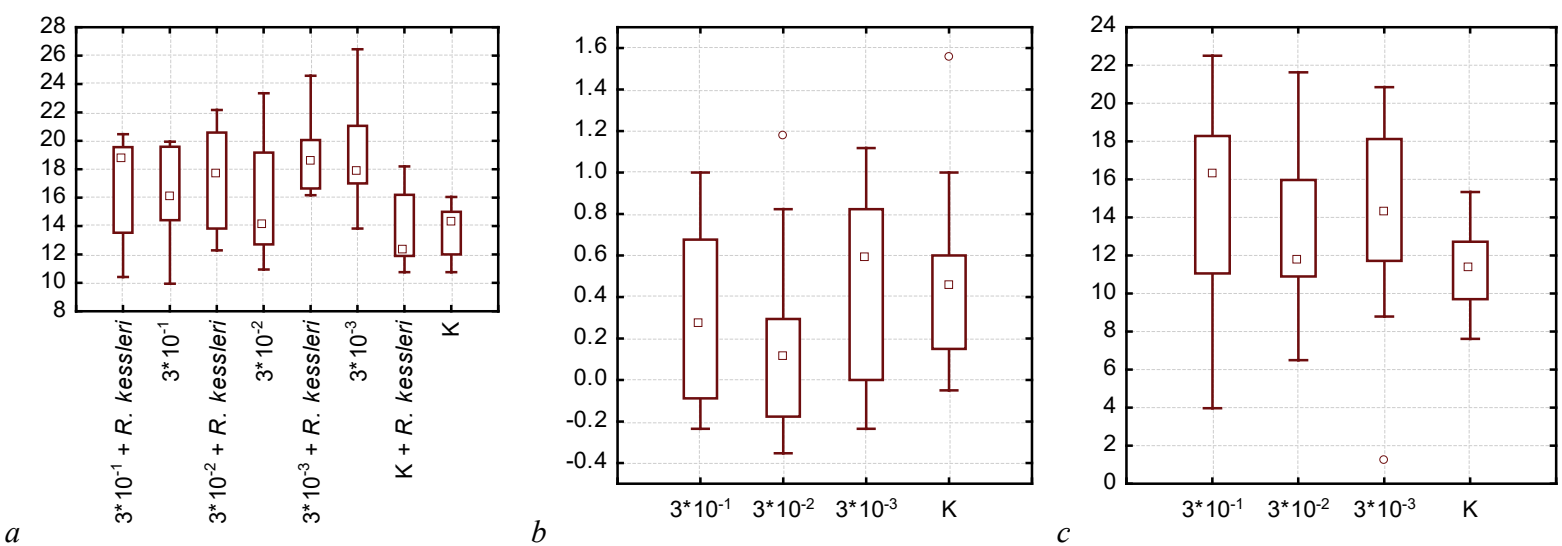

Fig. 2. Changes in food mass $(a)$, body weight of $(b)$, production of feces $(c)$ by the specimens of Rossiulus kessleri (Lohm.) during 20-h experiment in the gradient of the concentration of Urahan Forte preparation: on abscissa axis - concentration of active agent of Urahan Forte (potassium salt of glyphosate, $\mathrm{mg} / \mathrm{g}$ of litter), $\mathrm{K}$ - control (without Urahan Forte); on the ordinate axis - mean daily changes in the body weight, mass of food and feces $(\mathrm{mg} / 24 \mathrm{~h})$, respectively; $\mathrm{n}=10$ 

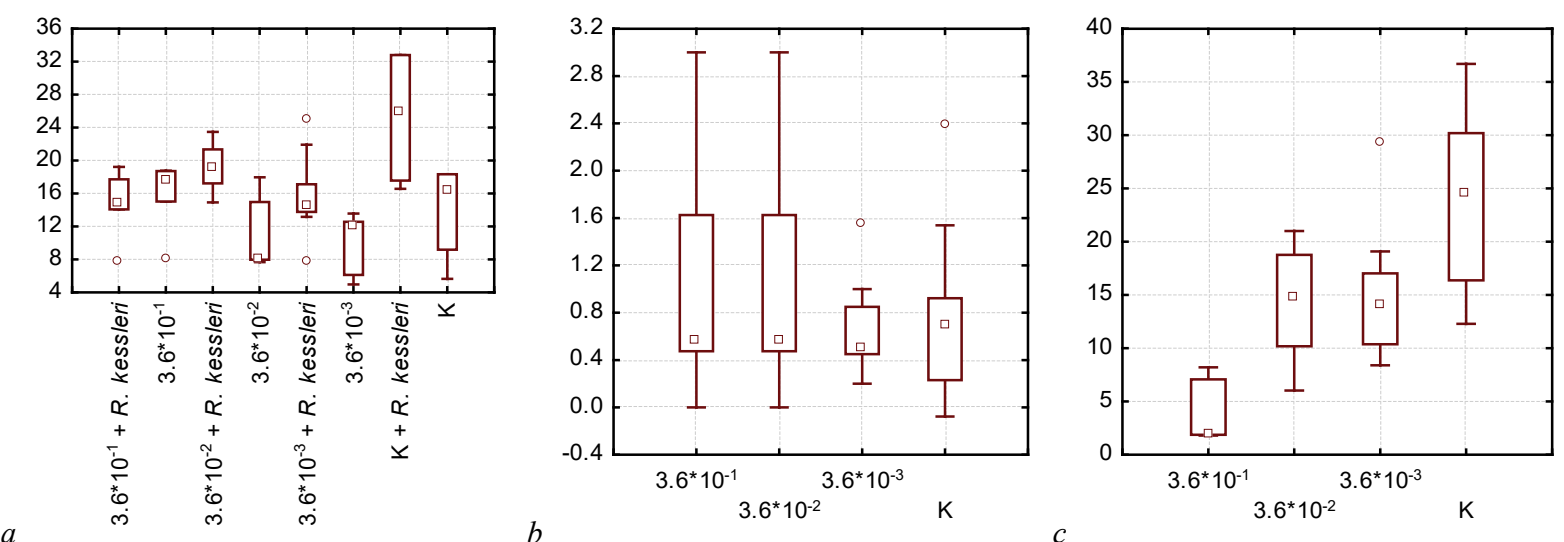

Fig. 3. Changes in the mass of food (a), body weight of (b), production of feces $(c)$ by specimens of Rossiulus kessleri (Lohm.) during 20-day experiment in the gradient of the concentration of Omite preparation: on abscissa axis - concentration of the active substance of Omite (mg/g of litter); K - control

(without influence of Omite); on ordinate axis - average daily change in body weight, mass of food or feces $(\mathrm{mg} / 24 \mathrm{~h}$ ), respectively; $\mathrm{n}=10$

Under the impact of BI-58 preparation, the rates of breakdown of litter increased: the median of this characteristic equaled $15 \mathrm{mg} / 24 \mathrm{~h}$ in the conditions of absence of millipedes, and in the concentration of Dimethoate equaling $2.4 \cdot 10^{-3}-2.4 \cdot 10^{-1} \mathrm{mg} / \mathrm{g}$ of litter it increased practically by two times - to $26-28 \mathrm{mg} / 24 \mathrm{~h}$ (Fig. 4a). Specimens of $R$. kessleri reliably did not increase the rates of breakdown of litter when exposed to the preparation BI-58 (Fig. 4b). Increase in the concentration of Dimethoate from $2.4 \cdot 10^{-2}$ to $2.4 \cdot 10^{-1} \mathrm{mg} / \mathrm{g}$ of litter caused reliable decrease in the body weight of $R$. kessleri by more than $4 \mathrm{mg} / 24 \mathrm{~h}$ (Fig. $4 b)$. Similar decrease for the tempi of formation of excrement was seen at increase in the concentration of dimethoate from $2.4 \cdot 10^{-3}$ to $2.4 \cdot 10^{-2}$ $\mathrm{mg} / \mathrm{g}$ of litter (Fig. 4c). Under the influence of low concentrations of the preparation Biotlin, the reliable differences between the variants of the experiment with and without $R$. kessleri millipedes were observed at the concentration higher than $1.2 \cdot 10^{-2} \mathrm{mg} / \mathrm{g}$ of litter (Fig. 5a). At maximum tested concentrations $\left(1.2 \cdot 10^{-1}\right.$ and $1.2 \cdot 10^{-2} \mathrm{mg} / \mathrm{g}$ of litter), body weight of $R$. kessleri reliably did not differ from the control variants of the experiment (Fig. 5b). Intensity of production of excrement by millipedes reliably decreased from 24 to $10-12 \mathrm{mg} / 24 \mathrm{~h}$ (median) at all three studied concentrations of Imidacloprid (Fig. 5c).

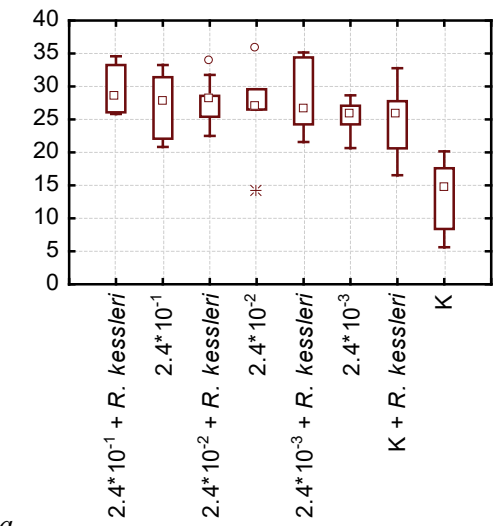

$a$

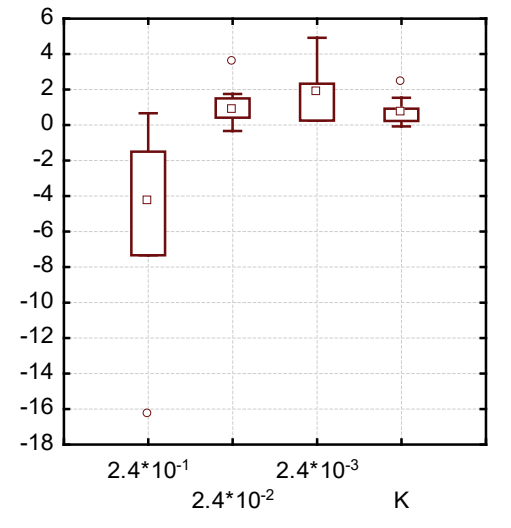

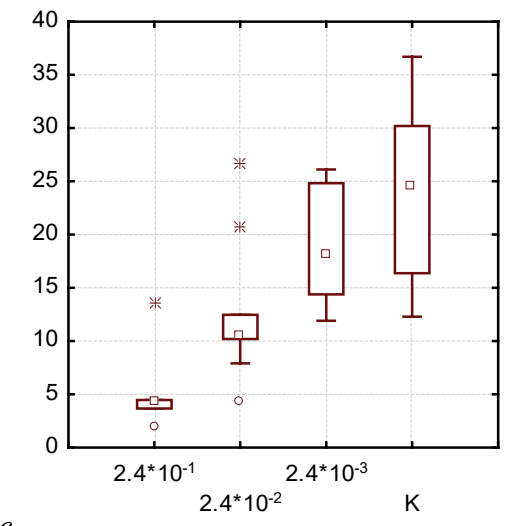

Fig. 4. Changes in the mass of food $(a)$, body weight of $(b)$, production of feces by $(c)$ specimens of Rossiulus kessleri (Lohm.) during 20-day experiment in the gradient of the concentration of BI-58 EC: on the abscissa axis - concentration of the active agent of BI-58 EC (dimethoate, $\mathrm{mg} / \mathrm{g}$ of litter), $\mathrm{K}$ - control (without exposure to БI-58 EC preparation); on ordinate axis - average daily change in body weight, mass of food or feces (mg/24 h), respectively; $\mathrm{n}=10$
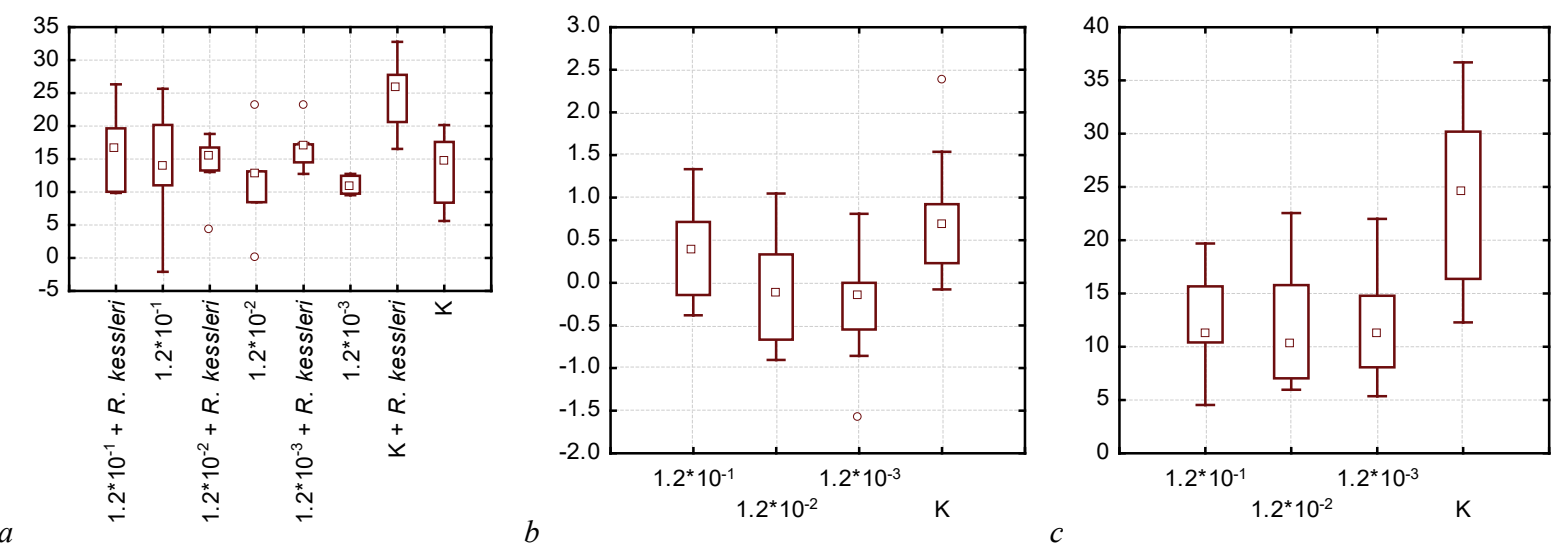

Fig. 5. Changes in the mass of food $(a)$, body weight of $(b)$, production of feces by $(c)$ the specimens of Rossiulus kessleri (Lohm.) over the 20-day experiment in the concentration of the preparation Biotlin: on the abscissa axis - concentration of active agent of Biotlin (Imidacloprid, $\mathrm{mg} / \mathrm{g}$ of litter),

$\mathrm{K}$ - control (without exposure to Biotlin); on ordinate axis - average daily changes in body weight, food or feces (mg/24h), respectively; $\mathrm{n}=10$ 
The preparation Actellic led to complete death of the millipedes in two variants of the experiment with maximum concentration of Pirimiphos-methyl $\left(3 \cdot 10^{-2}\right.$ and $3 \cdot 10^{-1} \mathrm{mg} / \mathrm{g}$ of litter). At the same time, food was not consumed by $R$. kessleri exposed to the Actellic concentration of $3 \cdot 10^{-3} \mathrm{mg} / \mathrm{g}$ of litter (Fig. 6a); under influence of this concentration, body weight (Fig. 6b) and tempi of formation of excrement decreased in millipedes unreliably (Fig. 6c).

Under the influence of the preparation Nurelle D, we observed 100\% death of $R$. kessleri while using the concentration of $3 \cdot 10^{-1} \mathrm{mg} / \mathrm{g}$ of litter. Even at the concentration of $3 \cdot 10^{-1} \mathrm{mg}$ of Chlorpyrifos/g of litter the millipedes continued to feed, and the differences between the mass of litter in the variants with and without millipedes were not reliable (Fig. 7a). In the control (without influence of the pesticide) the body weight of R. kessleri increased by $0.7 \mathrm{mg} / 24 \mathrm{~h}$, whereas at the concentration of $3 \cdot 10^{-2} \mathrm{mg}$ of Chlorpyrifos/g of litter their body weight decreased on average by $0.5 \mathrm{mg} / 24 \mathrm{~h}$ (Fig. 7b). Tempi of formation of feces during the influence of this concentration also reliably decreased from 24 to $7 \mathrm{mg} / 24 \mathrm{~h}$ (Fig. 7c).

Impact of fungicides Ridomil Gold, Thiovit Jet, Penncozeb 80 WP, Falcon, Tilt, Horus on R. kessleri. When exposed to Ridolmil Gold in the concentration of $4 \cdot 10^{-3} \mathrm{mg} / \mathrm{g}$, the individuals of $R$. kessleri continued to consume food in the same tempi as in the variant of the experiment without exposure to pesticides (Fig. 8a). Increase in the concentration of this pesticide to $4 \cdot 10^{-2} \mathrm{mg} / \mathrm{g}$ caused the millipedes to stop feeding. The body weight of the specimens reliably did not change (Fig. 8b), and the intensity of defecation reliably decreased (Fig. 8c) already at minimum of the tested concentrations of Ridomil Gold preparation. Thus, already in lowest tested concentration ( $4 \cdot 10^{-3} \mathrm{mg} / \mathrm{g}$ of litter), Ridomil Gold preparation had a negative impact on the metabolism of $R$. kessleri.

Introduction of the preparation Thiovite Jet to the litter, even in the highest concentrations, did not decrease food consumption by $R$. kessleri
(Fig. 9a). Interestingly, the addition of sulfate to the litter reliably increased the body weight of millipedes: median of gain in body weight increased from $0.7 \mathrm{mg} / 24 \mathrm{~h}$ in the control to $1.5-1.7 \mathrm{mg} / 24 \mathrm{~h}$ for the sulfate in the concentration of $4.8 \cdot 10^{-1}-4.8 \cdot 10^{-3} \mathrm{mg} / \mathrm{g}$ of litter (Fig. 9b). No reliable changes in the intensity of production of excrement were seen in the gradient of Thiovite Jet concentration (Fig. 9c). According to the results of the laboratory experiment, $R$. kessleri stopped consuming food affected already by average concentration of Penncozeb $80 \mathrm{WP}$ pesticide $-4.8 \cdot 10^{-2} \mathrm{mg}$ of Mancozeb/g of litter (Fig. 10a). Under the influence of Mancozeb, no reliable changes in body weight of millipedes were observed compared with the control (Fig. 10b), though the tempi of formation of excrement decreased by approximately two times already while using the concentration of $4.8 \cdot 10^{-2} \mathrm{mg} / \mathrm{g}$ of litter (Fig. 10c).

As with Falcon pesticide, reliable differences in the mass of litter between the variants of the experiment with and without $R$. kessleri remained during influence of the concentration of $1.1 \cdot 10^{-2} \mathrm{mg}$ of Tebuconazole $/ \mathrm{g}$ of litter (Fig. 11a); during the influence of highest concentration of Falcon, the food consumption of millipedes stopped. Body weight of $R$. kessleri in all the variants with this pesticide reliably did not differ from the control group of millipedes (Fig. 11b). Already the minimum tested concentration of this pesticide caused a reliable more than two-fold decrease in the tempi of formation of feces (Fig. 11c).

Exposure to Tilt preparation caused cessation of consumption of litter by millipedes already in minimum tested concentration of propiconazole $1.5 \cdot 10^{-3} \mathrm{mg} / \mathrm{g}$ of litter (Fig. 12a). Body weight of $R$. kessleri reliably did not change under the effect of Tilt compared with the control (Fig. 12b), though we observed a tendency towards decrease in body weight while using lowest tested concentration of the pesticide: perhaps, millipedes exposed to this concentration continued to consume food. Tempi of formation of feces also reliably did not change at increase in the concentration of Tilt (Fig. 12c).
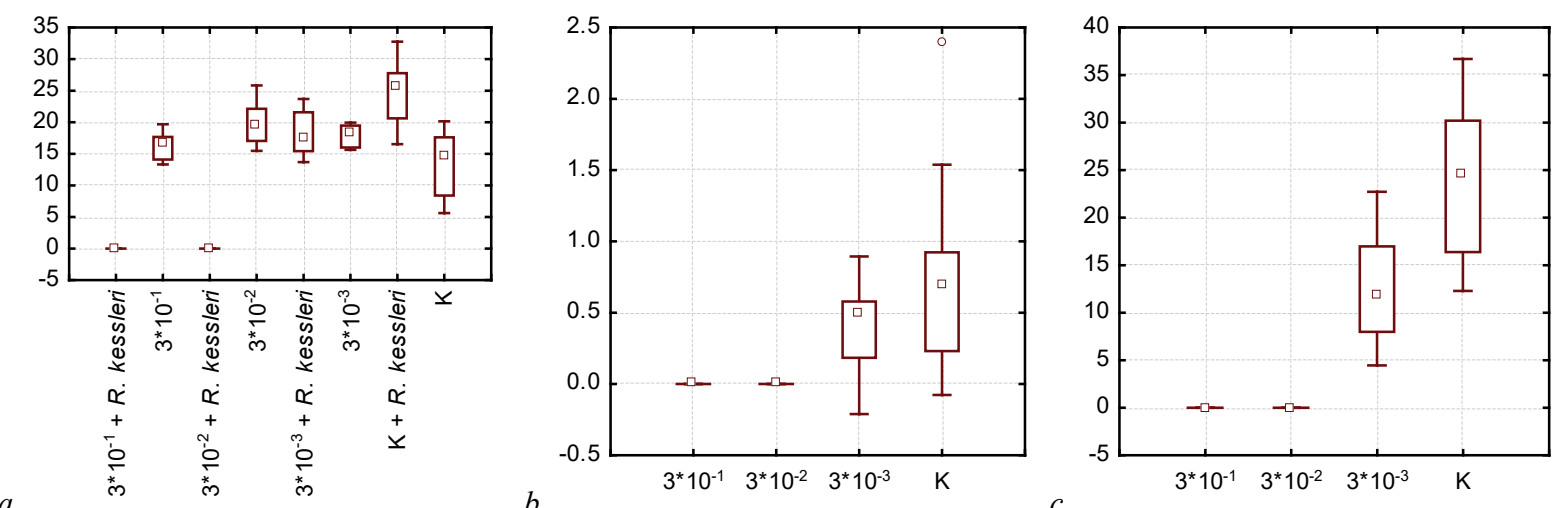

Fig. 6. Changes in mass of food $(a)$, body weight of $(b)$, production of feces $(c)$ by specimens of Rossiulus kessleri (Lohm.) over 20-day experiment in the gradient of the concentration of preparation Actellic: on the abscissa axis - concentration of active agent of Actellic (Pirimiphos-methyl, mg/g of litter), $\mathrm{K}$ - control (without exposure to Actellic); on the ordinate axis - average daily changes in body weight, mass of food or feces (mg/day), respectively; $\mathrm{n}=10$
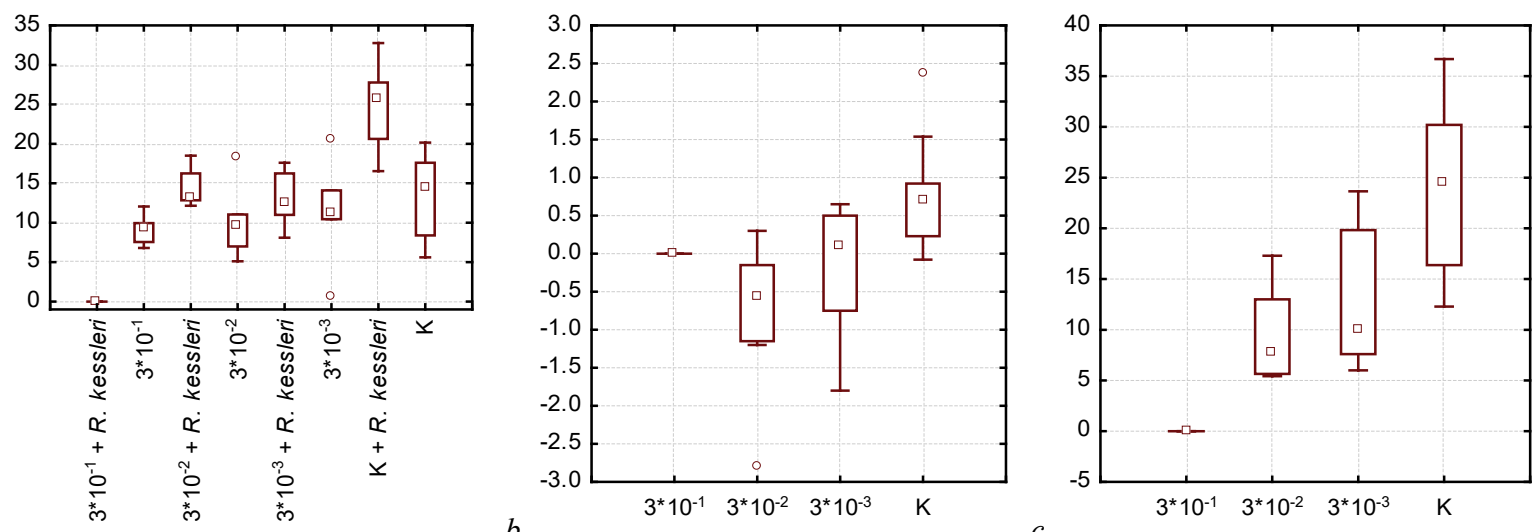

Fig. 7. Change in mass of fodder $(a)$, body weight $(b)$, production of feces $(c)$ by individuals of Rossiulus kessleri (Lohm.) over 20-day experiment in the gradient of concentration of Nurelle D: $24 \mathrm{~h}$ experiment in the concentration of preparation Nurelle D: on abscissa axis - concentration of active agent of Nurelle D preparation (mixture of Chlorpyrifos, $500 \mathrm{~g} / \mathrm{L}$, and Cypermethrin, $50 \mathrm{~g} / \mathrm{L}$, concentration is indicated according to Chlorpyrifos, $\mathrm{mg} / \mathrm{g}$ of litter), $\mathrm{K}$ - control (without exposure to Nurelle D); on the ordinate axis - mean daily changes in body weight, mass of food or feces ( $\mathrm{mg} / 24 \mathrm{~h}$ ), respectively; $\mathrm{n}=10$ 

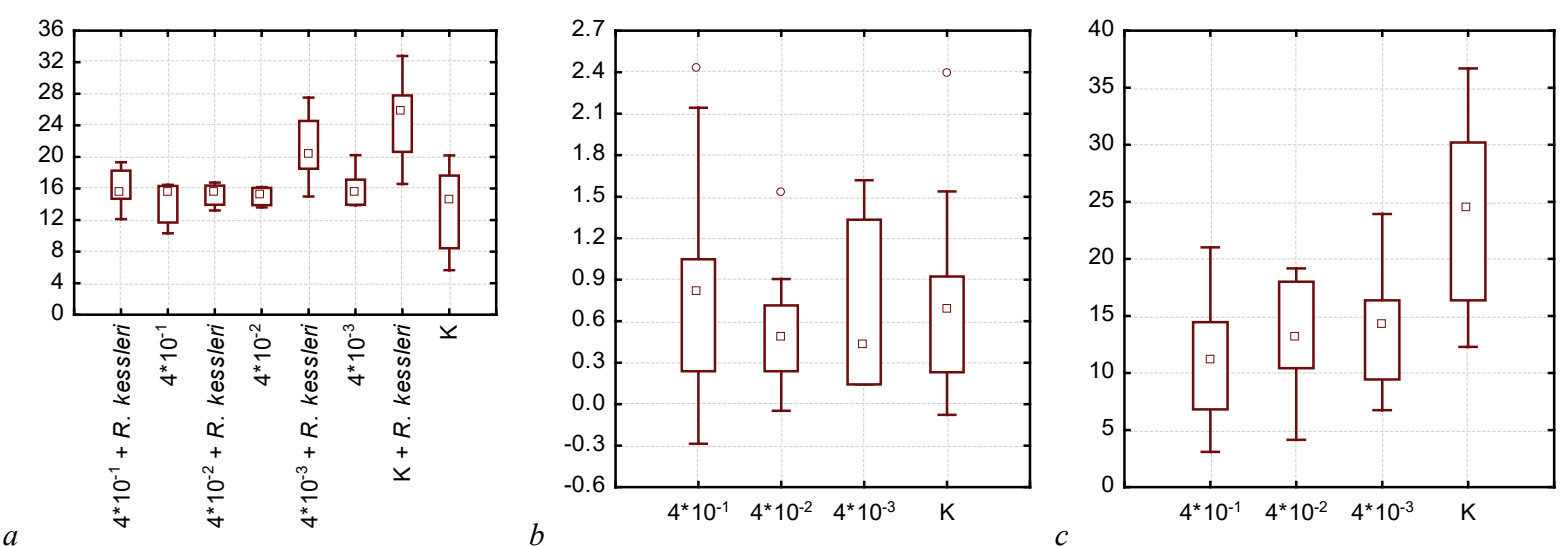

Fig. 8. Changes in mass of food $(a)$, body weight of $(b)$, production of feces $(c)$ by individuals of Rossiulus kessleri (Lohm.) over 20-day experiment in the gradient of concentration of the preparation Ridomil Gold: on abscissa axis - concentration of active substance of Ridomil Gold (mixture of Mefenoxam, $640 \mathrm{~g} / \mathrm{kg}$, and Mancozeb, $40 \mathrm{~g} / \mathrm{kg}$ of preparation; dosing is indicated according to Mefenoxam, $\mathrm{mg} / \mathrm{g}$ of litter), $\mathrm{K}$ - control (without exposure to Ridomil Gold); on ordinate axis - mean daily changes in body weight, mass of food or feces ( $\mathrm{mg} / 24 \mathrm{~h})$, respectively; $\mathrm{n}=10$
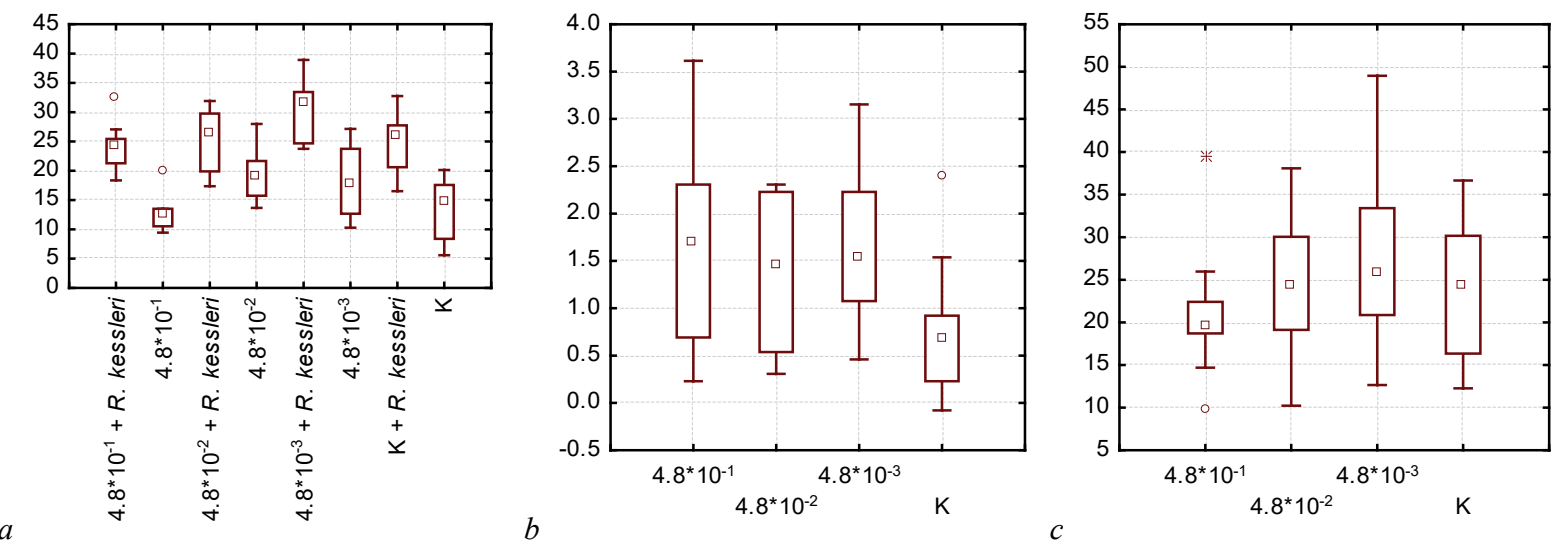

Fig. 9. Changes in mass of food $(a)$, body weight of $(b)$, production of feces $(c)$ by individuals of Rossiulus kessleri (Lohm.) over 20-day experiment in the gradient of concentration of the preparation: Thiovite Jet on abscissa axis - concentration of active substance of Thiovite Jet (sulfur, $\mathrm{mg} / \mathrm{g}$ of litter), $\mathrm{K}$ - control (without exposure to Thiovite Jet); on ordinate axis - mean daily changes in body weight, mass of food or feces ( $\mathrm{mg} / 24 \mathrm{~h}$ ), respectively; $\mathrm{n}=10$
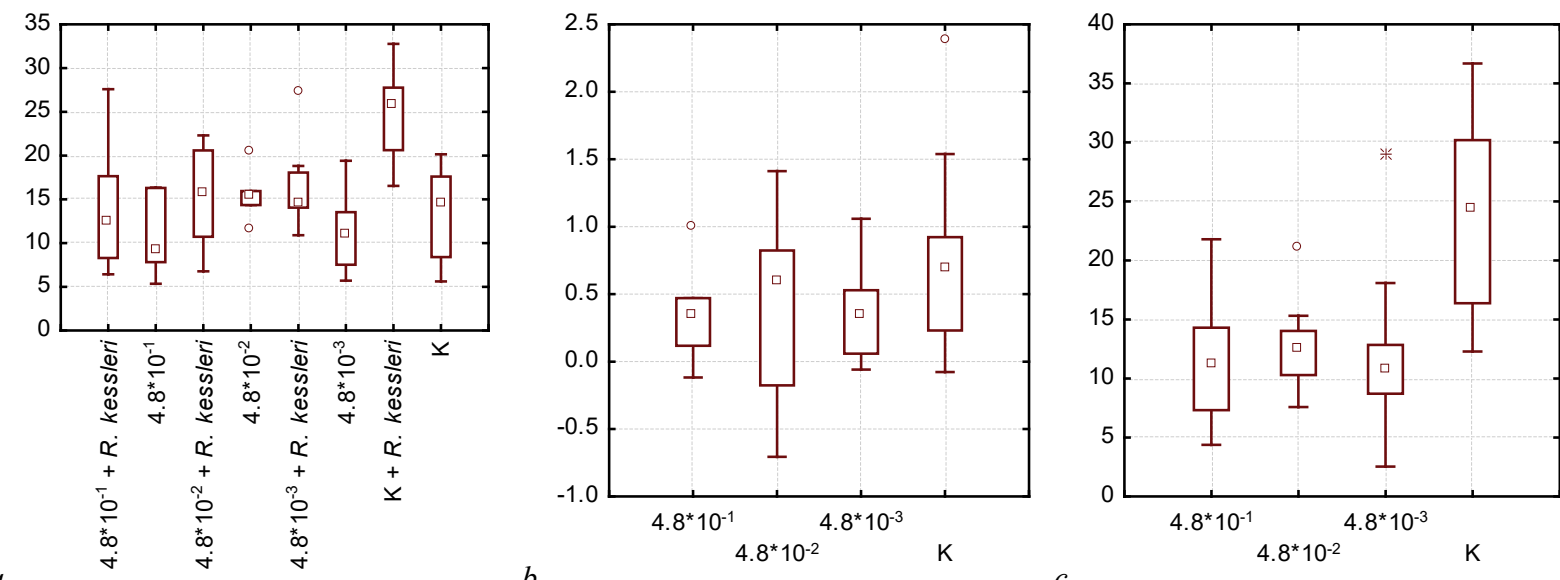

Fig. 10. Changes in mass of food $(a)$, body weight of $(b)$, production of feces $(c)$ by individuals of Rossiulus kessleri (Lohm.) over 20-day experiment in the gradient of concentration of preparation Penncozeb $80 \mathrm{WP}$ : on abscissa axis - concentration of active substance of Penncozeb $80 \mathrm{WP}$ (Mancozeb, mg/g of litter), $\mathrm{K}$ - control (without exposure to Penncozeb $80 \mathrm{WP}$ ); on ordinate axis - mean daily changes in body weight, mass of food or feces ( $\mathrm{mg} / 24 \mathrm{~h}$ ), respectively; $\mathrm{n}=10$

The preparation Horus had no reliable effect on food consumption of R. kessleri even in the highest tested concentration $-4.5 \cdot 10^{-1} \mathrm{mg}$ of cyprodinil/g of litter (Fig. 13a).

It is interesting that the lowest of the tested concentrations $\left(4.5 \cdot 10^{-3}\right.$ $\mathrm{mg}$ of cyprodinil/g of litter) caused maximum increase in the body weight of the millipedes: from 0.7 to $1.9 \mathrm{mg} / 24 \mathrm{~h}$ (Fig. 13b). The tempi of formation of excrement reliably did not change at increase in the concentra- tion of cyprodinil in the food of the millipedes (Fig. 13c). Finally, we should note (Table 2) that the food treated with the large amount of the pesticides we tested did not absorb in the intestine during the experiment, remaining there and therefore poisoning the millipedes.

Each of the preparations in the tested concentrations either inhibited food consumption and formation of excrement or underlay decrease in body weight of the tested animals. 

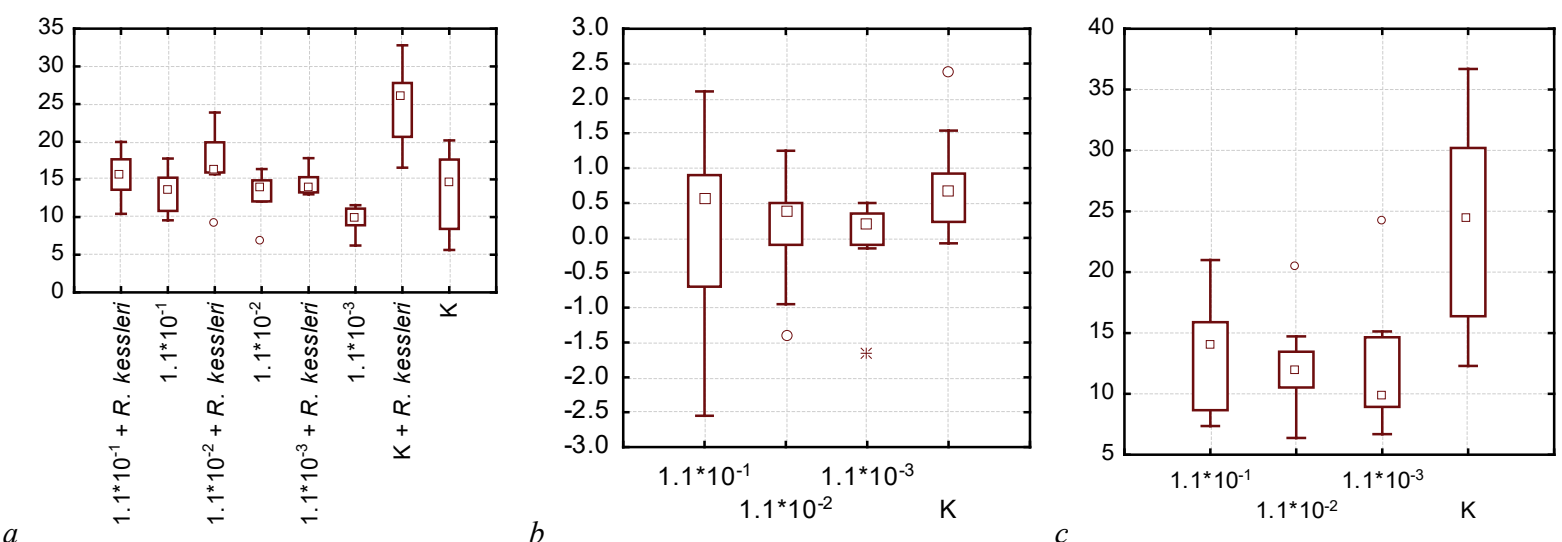

Fig. 11. Changes in mass of food ( $a$ ), body weight of $(b)$, production of feces (c) by individuals of Rossiulus kessleri (Lohm.) over 20-day experiment in the gradient of concentration of the preparation Falcon: on abscissa axis - concentration of active substance of Falcon (mixture of Tebuconazole, $167 \mathrm{~g} / \mathrm{L}$, triadimenol, $43 \mathrm{~g} / \mathrm{L}$, and spiroxamine, $250 \mathrm{~g} / \mathrm{L}$, concentration os indicated according to Tebuconazole, $\mathrm{mg} / \mathrm{g}$ of litter), $\mathrm{K}$ - control (without exposure to Falcon); on ordinate axis - mean daily changes in body weight, mass of food or feces ( $\mathrm{mg} / 24 \mathrm{~h})$, respectively; $\mathrm{n}=10$
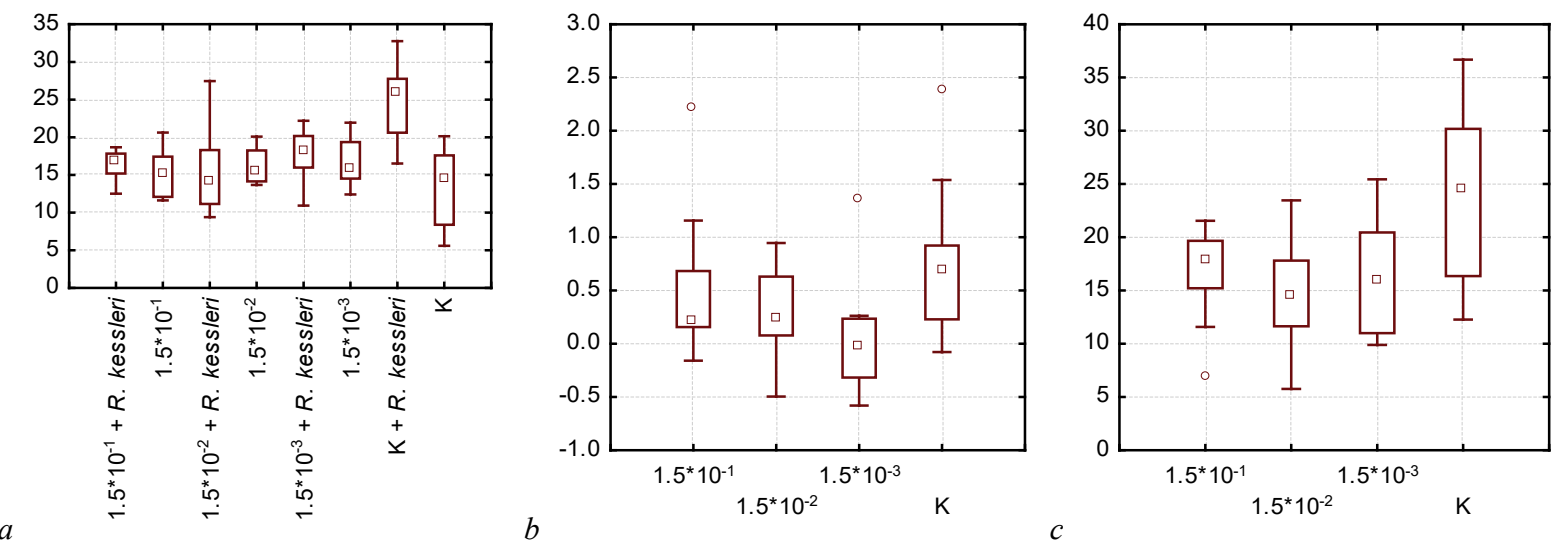

Fig. 12. Changes in mass of food $(a)$, body weight of $(b)$, production of feces $(c)$ by individuals of Rossiulus kessleri (Lohm.) over 20-day experiment in the gradient of concentration of the preparation Tilt: on abscissa axis - concentration of active substance of Tilt (propiconazole, $\mathrm{mg} / \mathrm{g}$ of litter), $\mathrm{K}$ - control (without exposure to Tilt); on ordinate axis - mean daily changes in body weight, mass of food or feces ( $\mathrm{mg} / 24 \mathrm{~h}$ ), respectively; $\mathrm{n}=10$
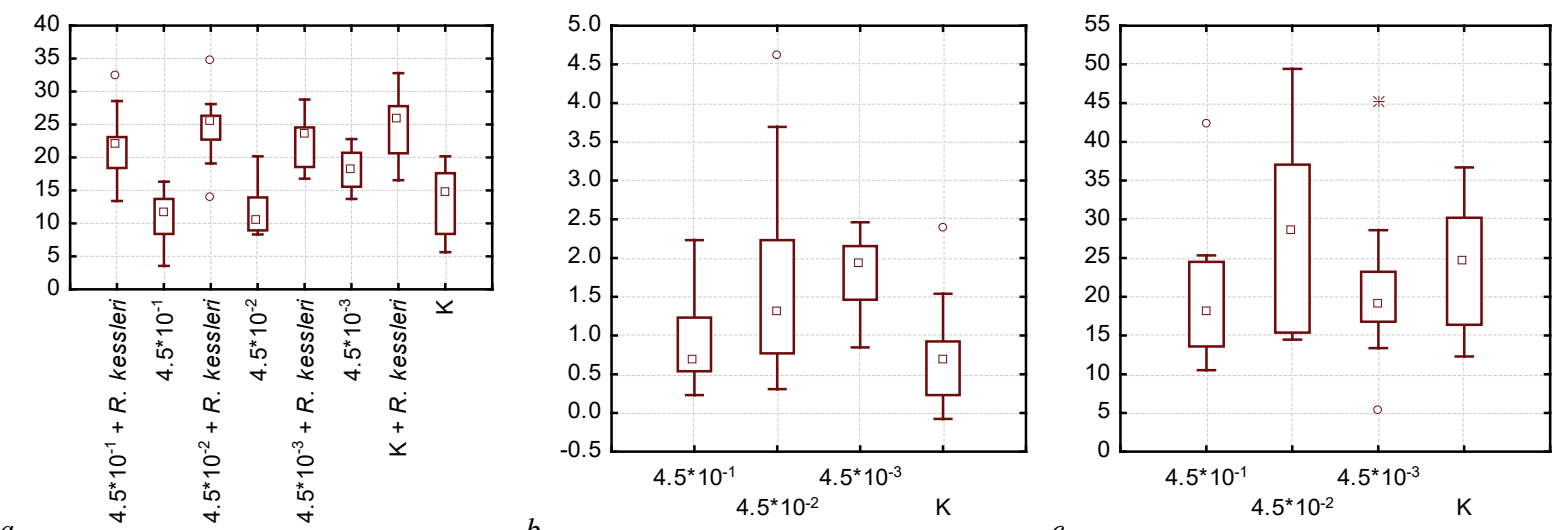

Fig. 13. Changes in mass of food $(a)$, body weight of $(b)$, production of feces $(c)$ by individuals of Rossiulus kessleri (Lohm.) over 20-day experiment in the gradient of concentration of the preparation Horus: on abscissa axis - concentration of active substance of Horus (cyprodinil, $\mathrm{mg} / \mathrm{g}$ of litter),

$\mathrm{K}$ - control (without exposure to Horus); on ordinate axis - mean daily changes in body weight, mass of food or feces ( $\mathrm{mg} / 24 \mathrm{~h}$ ), respectively; $\mathrm{n}=10$

\section{Discussion}

Agricultural production in the current conditions is impossible without use of pesticides (Relyea, 2004; Pardon et al., 2019). Agrocenoses the biocenoses created and managed by man, - may develop certain productivity only in the conditions of constant maintenance of the composition of plants and invertebrates. Only a small part of pesticides introduced into agrocenoses reaches their target (eradicates species of organisms which are harmful to humans ), while the rest destroy non-target organ- isms, remaining in the areas adjacent to the agrocenoses. Negative consequences related to introduction of pesticides involve not only direct killing of living organisms, but first of all change in the soil-forming processes: disturbance of the balance between humification (ingress of partially dissolved organic substances into the higher layers of soil which increases its fertility) and mineralization (destruction of organic compounds to carbon dioxide, atmospheric nitrogen and soluble salts which ingress into the atmosphere and groundwater). Balance between mineralization and humification is maintained first of all by the bacteria and fungi, and by soil 
animals to a lesser extent. Ingress of pesticides to the litter changes the proportion between bacteria, fungi and animals in the food chains of the detritus ecosystem. The abundance of separate species of living organisms in the soil and litter is closely associated with the interactions of these species (Brygadyrenko, 2015, 2016). Absence of one or presence of other bacteria and fungi can slow the digestion of food by the organisms of invertebrates (Byzov, 2006). Residual amounts of pesticides accumulate in trophic chains, part of these excess amounts of pesticides spread beyond the borders of the treated territory (Jabin et al., 2004; Goßner et al., 2006). However, the potential danger of many pesticides to soil biota is studied insufficiently (Hopkin, 1990).

Mass death of predatory and parasitic animals caused by chemicals which regulate the number of phytophages leads to growth of plantfeeding organisms which in the conditions of absence of natural enemies quickly increase their populations - the so-called "pesticide syndrome" develops. Sub-lethal doses of insecticides may cause changes in the behaviour of individuals, causing changes in the spatial structure of their populations (vertical distribution of individuals in litter and on the surface of soil). Changes in the composition of fauna beneficial to humans after the treatment with pesticides may be reflected in species composition of pests in agrocenoses. At the same time, old and well-known pests become replaced by new pests - species which are rare and economically insignificant at the beginning of the process (Pardon et al., 2019). Threat increases also due to the fact that some pesticides can remain in the soil for many years. Even the lowest concentrations of them could be dangerous for soil saprophages (Hopkin, 1990). Small concentrations of pesticides in many cases inhibit the immune system, often exerting allergic, carcinogenic and mutagenic actions towards invertebrates and humans.

\section{Table 2}

Evaluation of effects of pesticides on food consumption, changes in body weight of and rates of formation of feces by $R$. kessleri

\begin{tabular}{|c|c|c|c|}
\hline Products & $\begin{array}{c}\text { Concentration } \\
\text { which causes stop in feeding, } \mathrm{mg} / \mathrm{g}\end{array}$ & $\begin{array}{l}\text { Concentration causing reliable change } \\
\text { in body weight, } \mathrm{mg} / \mathrm{g}\end{array}$ & $\begin{array}{l}\text { Concentration which impairs tempi } \\
\text { of formation of feces, } \mathrm{mg} / \mathrm{g}\end{array}$ \\
\hline Roundup & $2.8 \cdot 10^{-1}, 2.8 \cdot 10^{-2} \mathrm{i} 2.8 \cdot 10^{-3}$ & unreliably & $2.8 \cdot 10^{-2} \mathrm{i} 2.8 \cdot 10^{-3}$ \\
\hline Urahan Forte & $3 \cdot 10^{-1}, 3 \cdot 10^{-2}$ & unreliably & $3 \cdot 10^{-1}$ \\
\hline Omite & unreliably & unreliably & $3.6 \cdot 10^{-1}$ \\
\hline Ridomil Gold & $4 \cdot 10^{-2}$ & unreliably & $4 \cdot 10^{-3}$ \\
\hline BI-58 EC & unreliably & $2.4 \cdot 10^{-2}$ до $2.4 \cdot 10^{-1}$ & $2.4 \cdot 10^{-3}$ до $2.4 \cdot 10^{-2}$ \\
\hline Biotlin & $1.2 \cdot 10^{-1}$ i $1.2 \cdot 10^{-2}$ & $1.2 \cdot 10^{-1} \mathrm{i} 1.2 \cdot 10^{-2}$ & $1.2 \cdot 10^{-1} \mathrm{i} 1.2 \cdot 10^{-2}$ \\
\hline Thiovit Jet & unreliably & $4.8 \cdot 10^{-1}-4.8 \cdot 10^{-3}$ & unreliably \\
\hline Penncozeb $80 \mathrm{WP}$ & $4.8 \cdot 10^{-2}$ & unreliably & $4.8 \cdot 10^{-2}$ \\
\hline Actellic & $3 \cdot 10^{-3}$ & unreliably & unreliably \\
\hline Nurelle D & $3 \cdot 10^{-1}$ & $3 \cdot 10^{-2}$ & - \\
\hline Falcon & - & $1.1 \cdot 10^{-2}$ & $1.1 \cdot 10^{-3}$ \\
\hline Tilt & $1.5 \cdot 10^{-3}$ & unreliably & unreliably \\
\hline Horus & unreliably & $4.5 \cdot 10^{-3}$ & - \\
\hline
\end{tabular}

Metabolic processes in insects are usually more intense compared with diplopods, whereas decrease in the body weight in the similar experiments is not seen often (Shulman et al., 2017; Martynov \& Brygadyrenko, 2017, 2018a, 2018b). Usually death of insects is observed already after cessation of consumption of food with a certain toxic substance. Diplopods are able to fall into summer diapause in the conditions of dry climate or digest the consumed food very slowly in certain conditions (Kaneko, 1999; Kozak \& Brygadyrenko, 2018). This allows one to determine a quite long phase of slowing in the consumption of food or phase of thinning of animals during laboratory experiments.

In our experiment we surveyed the effects of insecticides, fungicides and herbicides on $R$. kessleri - species of saprophage that usually develops 5-6 years (Striganova, 1972). This means that during several vegetation seasons, this species can accumulate various types of pesticides introduced by farmers in different years to various plants of field crop rotations. At the same time, accumulation of pesticides in $R$. kessleri can cause dysbalance in the compositions of gut microbiota or parasites of its intestine (Guzev \& Byzov, 2006; Brygadyrenko \& Svyrydchenko, 2015; Moreira-de-Sousa et al., 2017; Reshetniak et al., 2017). This can change the extent of digestion of food in the organism of $R$. kessleri, as we observed in the experiment: food consumption slows (1), as well as evacuation of feces from the intestine (2) or consumption of food and digestion (3), causing decrease in the total body weight of the animals throughout the experiment. When these processes intensified (in the conditions of increase in the concentration of pesticides in food), the millipedes were observed to die. In this survey our purpose was not to determine the changes in gut microbiota or parasites of $R$. kessleri, but we are confident that these changes will also be observed during exposure to pesticides.

Unlike insects, a large number of which are able to fly or run fast, diplopods cannot migrate fast (Attems, 1927). The areas of their populations in the territory of our surveys (steppe zone of Ukraine) are quite limited. Though $R$. kessleri is the commonest representative of this class of animals in the south of Ukraine, even in steppe zone it is not that abundant, occurring only in each fourth-fifth ecosystem we surveyed in the period of over twenty years (Brygadyrenko, 2015, 2016). Despite the fact that in some populations of Southern Ukraine the number of $R$. kessleri reaches $50-100$ specimens per square meter, in general the species distribution is quite limited. Increase in use of pesticides in agrocenosises can lead to their accumulation in the organisms of $R$. kessleri. This species can be considered a regulator of soil-forming processes in Southern Ukraine, and its loss due to pesticide pollution of the environment will have a negative impact on fertility of soils in our country.

\section{Conclusion}

Individuals of $R$. kessleri exposed to herbicides Roundup and Urahan were observed to have no reliable change in their body weight, but the intensity of food consumption and formation of feces increased. Food processed with these herbicides was not absorbed in the intestines of millipedes, but in the period of 20 days they did not die.

In most cases, during the influence of Omite, BI-58, Biotlin, Actellic and Nurelle D insecticides on litter, changes in the amount of consumed food were unreliable. Under the influence of many of the insecticides we used, the amount of excrements of millipedes reliably decreased, and the body weight of the animals reliably did not increase. This indicates that the food treated with the insecticides in the tested concentrations was not absorbed in the intestine, remaining there and thus gradually poisoning the animals. Less often, the applied pesticides caused death of millipedes (Actellic and Nurelle D).

During the use of Ridomil Gold, Thiovit Jet, Penncozeb 80 WP, Falcon, Tilt and Horus, the amount of excrements reliably decreased or remained with no changes; the body weight of millipedes increased or did not change. The surveyed fungicides affect the animals differently depending on the concentration in the litter.

The determined patterns suggest that $R$. kessleri in agrocenoses and forest ecosystems bordering them (windbreaks, ravine or floodplain forests) can be significantly affected by the manufacture-recommended doses of pesticides and over ten-fold lower doses. The organism of $R$. kessleri is quite an inert system which during 20 days can limit the food consumption without significant effect on vitality. Therefore similar experiments should be carried out for a longer period of time.

\section{References}

Adamski, Z., Bloszyk, J., Bruin, J., \& Ziemnicki, K. (2007). Non-omnia moriantur toxicity of mancozeb on dead wood microarthropod fauna. Experimental and Applied Acarology, 42(1), 47-53. 
Attems, C. M. T. graf von (1927). Über Palaearktische Diplopoden. Archiv für Naturgeschichte, 92(1-2), 1-256.

Birkhofer, K., Dietrich, C., John, K., Schorpp, Q., Zaitsev, A. S., \& Wolters, V. (2016). Regional conditions and land-use alter the potential contribution of soil arthropods to ecosystem services in grasslands. Frontiers in Ecology and Evolution, 3,150 .

Brygadyrenko, V. V. (2015). Community structure of litter invertebrates of forest belt ecosystems in the Ukrainian steppe zone. International Journal of Environmental Research, 9(4), 1183-1192.

Brygadyrenko, V. V. (2016). Effect of canopy density on litter invertebrate community structure in pine forests. Ekológia (Bratislava), 35(1), 90-102.

Brygadyrenko, V. V., \& Svyrydchenko, A. O. (2015). Influence of the gregarine Stenophora julipusilli (Eugregarinorida, Stenophoridae) on the trophic activity of Rossiulus kessleri (Diplopoda, Julidae). Folia Oecologica, 42(1), 10-20.

Brygadyrenko, V., \& Ivanyshyn, V. (2015). Changes in the body mass of Megaphyllum kievense (Diplopoda, Julidae) and the granulometric composition of leaf litter subject to different concentrations of copper. Journal of Forest Science, 61(9), 369-376.

Byzov, B. A. (2006). Intestinal microbiota of millipedes. In: König, H., \& Varma, A. (Eds.). Intestinal microorganisms of termites and other invertebrates. Springer, Berlin. Pp. 89-114.

De Souza, R. B., Moreira-de-Sousa, C., Ansoar-Rodríguez, Y., Coelho, M. P. M., de Souza, C. P., Bueno, O. C., \& Fontanetti, C. S. (2019). Histopatology and HSP70 analysis of the midgut of Rhinocricus padbergi (Diplopoda) in the evaluation of the toxicity of two new metallic-insecticides. Environmental Science and Pollution Research, 27(3), 3023-3033.

Douglas, J., Hoffmann, A., Umina, P., \& Macfadyen, S. (2019). Factors influencing damage by the portuguese millipede, Ommatoiulus moreleti (Julida: Julidae), to crop seedlings. Journal of Economic Entomology, 112(6), 2695-2702.

Douglas, J., Macfadyen, S., Hoffmann, A., \& Umina, P. (2017). Crop seedling susceptibility to Armadillidium vulgare (Isopoda: Armadillidiidae) and Ommatoiulus moreletii (Diplopoda: Iulidae). Journal of Economic Entomology, 110(6), 2679-2685.

Ebregt, E., Struik, P. C., Odongo, B., \& Abidin, P. E. (2005). Pest damage in sweet potato, groundnut and maize in North-Eastern Uganda with special reference to damage by millipedes (Diplopoda). NJAS - Wageningen Journal of Life Sciences, 53(1), 49-69.

Evsyukov, A. P., \& Golovatch, S. I. (2013). Millipedes (Diplopoda) from the Rostov-on-Don Region, Southem Russia. Arthropoda Selecta, 22(3), 207-215.

Gere, G. (1956). Examination of the feeding biology and humification function of Diplopoda and Isopoda. Acta Biologica Hungarica, 6, 257-271.

Golovatch, S. I. (2008). On three remarkable millipedes (Diplopoda) from the Crimea, Ukraine. International Journal of Myriapodology, 1,97-110.

Golovatch, S. I., \& Kime, R. D. (2009). Millipede (Diplopoda) distributions: A review. Soil Organisms, 81(3), 565-597.

Goßner, M., Engel, K., \& Ammer, U. (2006). Effects of selection felling and gap felling on forest arthropod communities: A case study in a spruce-beech stand of Southern Bavaria. European Journal of Forest Research, 125(4), 345-360.

Guzev, V. S., \& Byzov, B. A. (2006). Morphometric analysis of bacteria associated with soil millipedes. Microbiology, 75(2), 219-225.

Hopkin, S. P. (1990). Critical concentrations, pathways of detoxification and cellular ecotoxicology of metals in terrestrial arthropods. Functional Ecology, $4(3), 321-327$.
Jabin, M., Mohr, D., Kappes, H., \& Topp, W. (2004). Influence of deadwood on density of soil macro-arthropods in a managed oak-beech forest. Forest Ecology and Management, 194, 61-69.

Kaneko, N. (1999). Effect of millipede Parafontaria tonominea Attems (Diplopoda: Xystodesmidae) adults on soil biological activities: A microcosm experiment. Ecological Research, 14(3), 271-279.

Kokhia, M. S., \& Golovatch, S. I. (2020). Diversity and distribution of the millipedes (Diplopoda) of Georgia, Caucasus. ZooKeys, 930, 199-219.

Kozak, V. M., \& Brygadyrenko, V. V. (2018). Impact of cadmium and lead on Megaphyllum kievense (Diplopoda, Julidae) in a laboratory experiment. Biosystems Diversity, 26(2), 128-131.

Lohmander, H. (1927). Schizophyllum kessleri n. sp., ein neuer Diplopode aus Südwestrußland. Zoologischer Anzeiger, 72(9-10), 225-230.

Martynov, V. O., \& Brygadyrenko, V. V. (2017). The influence of synthetic food additives and surfactants on the body weight of larvae of Tenebrio molitor (Coleoptera, Tenebrionidae). Biosystems Diversity, 25(3), 236-242.

Martynov, V. O., \& Brygadyrenko, V. V. (2018a). The impact of some inorganic substances on change in body mass of Tenebrio molitor (Coleoptera, Tenebrionidae) larvae in a laboratory experiment. Folia Oecologica, 45(1), 24 32.

Martynov, V. O., \& Brygadyrenko, V. V. (2018b). The influence of the synthetic food colourings tartrazine, allura red and indigo carmine on the body weight of Tenebrio molitor (Coleoptera, Tenebrionidae) larvae. Regulatory Mechanisms in Biosystems, 9(4), 479-484.

Moreira-de-Sousa, C., Iamonte, M., \& Fontanetti, C. S. (2017). Midgut of the diplopod Urostreptus atrobrunneus: Structure, function, and redefinition of hepatic cells. Brazilian Journal of Biology, 77(1), 132-139.

Pardon, P., Reheul, D., Mertens, J., Reubens, B., De Frenne, P., De Smedt, P., Proesmans, W., Van Vooren, L., \& Verheyen, K. (2019). Gradients in abundance and diversity of ground dwelling arthropods as a function of distance to tree rows in temperate arable agroforestry systems. Agriculture, Ecosystems and Environment, 270-271, 114-128.

Prisnyi, A. V. (2002). A review of the millipede fauna of the south of the MiddleRussian upland, Russia (Diplopoda). Arthropoda Selecta, 10, 297-305.

Relyea, R. A. (2005). The impact of insecticides and herbicides on the biodiversity and productivity of aquatic communities. Ecological Applications, 15(2), 618-627.

Reshetniak, D. Y., Pakhomov, O. Y., \& Brygadyrenko, V. V. (2017). Possibility of identifying plant components of the diet of Harpalus rufipes (Coleoptera, Carabidae) by visual evaluation. Regulatory Mechanisms in Biosystems, $8(3), 377-383$

Shulman, M. V., Pakhomov, O. Y., \& Brygadyrenko, V. V. (2017). Effect of lead and cadmium ions upon the pupariation and morphological changes in Calliphora vicina (Diptera, Calliphoridae). Folia Oecologica, 44(1), 28-37.

Striganova, B. R. (1972). Effect of temperature on the feeding activity of Sarmatiulus kessleri (Diplopoda). Oikos, 23(2), 197-199.

Striganova, B. R., \& Prishutova, Z. G. (1990). Food requirements of diplopods in the dry steppe subzone of the USSR. Pedobiologia, 34, 37-41.

Svyrydchenko, A. O., \& Brygadyrenko, V. V. (2014). Trophic preferences of Rossiulus kessleri (Diplopoda, Julidae) for the litter of various tree species. Folia Oecologica, 41(2), 202-212.

Tóth, Z., \& Hornung, E. (2019). Taxonomic and functional response of millipedes (Diplopoda) to urban soil disturbance in a metropolitan area. Insects, 11(1), 25. 